\title{
Steam co-gasification of brown seaweed and land-based biomass
}

\author{
Malinee Kaewpanha ${ }^{\mathrm{a}}$, Guoqing Guan ${ }^{\mathrm{a}, \mathrm{b}^{*}}$, Xiaogang $\mathrm{Hao}^{\mathrm{c}}$, Zhongde Wang ${ }^{\mathrm{c}}$, \\ Yutaka Kasai $^{\text {d }}$, Katsuki Kusakabe ${ }^{\mathrm{e}}$, Abuliti Abudula ${ }^{\mathrm{a}, \mathrm{b}^{*}}$ \\ ${ }^{a}$ Graduate School of Science and Technology, Hirosaki University, 1-Bunkyocho, Hirosaki \\ 036-8560, Japan \\ ${ }^{b}$ North Japan Research Institute for Sustainable Energy (NJRISE), Hirosaki University, 2-1-3, \\ Matsubara, Aomori 030-0813, Japan \\ ${ }^{c}$ Department of Chemical Engineering, Taiyuan University of Technology, Taiyuan 030024, \\ China \\ ${ }^{d}$ Industrial Research Institute, Aomori Prefectural Industrial Technology Research Center, \\ 4-11-6, Second Tonyamachi, Aomori 030-0113, Japan \\ ${ }^{e}$ Department of Nanoscience, Sojo University, 4-22-1 Ikeda, Nishi-ku, Kumamoto 860-0082, \\ Japan
}

*Corresponding authors. Tel.: +81-17-762-7756; Fax: +81-17-735-5411

E-mail addresses: guan@cc.hirosaki-u.ac.jp (G. Guan); abuliti@cc.hirosaki-u.ac.jp (A. Abudula) 


\section{Abstract}

Alkali and alkaline earth species in biomass have self-catalytic activity on the steam gasification to produce hydrogen-rich gas. In this study, three types of biomasses, i.e., brown seaweed, Japanese cedar, apple branch containing different concentrations of alkali and alkaline earth species, and the mix of both of them were gasified with steam in a fixed-bed reactor under atmospheric pressure. The effects of reaction temperature, steam amount and mixing ratio in co-gasification on gas production yields were investigated. The results showed that higher gas production yields (especially for $\mathrm{H}_{2}$ and $\mathrm{CO}_{2}$ ) were obtained than other two types of biomasses when the brown seaweed was used since the ash content in brown seaweed was much higher than land-based biomasses and contained a large amount of alkali and alkaline earth species. The yield of hydrogen increased with an increase in the amount of steam, but excessive steam use reduced the hydrogen production yield. From the co-gasification experiments, the gas production yields (especially for $\mathrm{H}_{2}$ and $\mathrm{CO}_{2}$ ) from the land-based biomasses increased with the increase in brown seaweed ratio, suggesting that the alkali and alkaline earth species in brown seaweed acted as the catalysts to enhance the gasification of land-based biomass in co-gasification process.

Keywords: Biomass; Steam gasification; Co-gasification; Seaweed, Alkali and alkaline earth metals 


\section{Introduction}

With the depletion of fossil fuel sources as well as the global warming issues, much attention has been paid to those renewable energy sources such as biomass which can be converted to clean fuels via thermo-chemical and biochemical routes [1,2]. Among all biomass thermochemical conversion processes, gasification is considered one of the promising ways carried out at high temperatures to convert energy content of biomass into a more practical and clean fuel, which can be used for synthesis of methanol and other liquid fuels by Fischer-Tropsch synthesis, chemical production, and electricity generation (turbine, gas engine or fuel cell) [3-5]. However, in biomass gasification, significant amounts of tar generally generated together with syngas should be removed out from the gas lines. In fact, tar can condense into more complex structures and difficult to remove [6-8]. To date, it is found that steam gasification of biomass can produce a gaseous fuel with a relatively higher $\mathrm{H}_{2}$ content having relatively low tar content [9]. A large number of papers have been published dealing with the gasification of various land-based biomasses, including sawdust [10], cedar wood [11], camphor wood [12], pine wood [13], rice straw [14] and white oak [15], and so on. Besides land-based biomass, seaweeds (macroalgae) are gaining increasing interest as a feedstock for sustainable fuels production. Some seaweeds really have numerous advantages over other land-based biomasses for the following reasons: high growth rate, high mass productivity per 
area, no need for internal transport of nutrients or water and no competition with food production [16]. Many researches in energy and fuels relating to algae have been devoted towards methane production and biodiesel production from microalgae, very few studies have investigated the conversion of macroalgae to syngas by gasification which can be used directly for energy production $[17,18]$. Seaweeds can be subdivided into three broad groups, namely, red algae, brown algae and green algae, based on their pigmentation [19]. Among different types of seaweeds, brown seaweed has relatively low protein content but is very rich in carbohydrate content. This feature of brown seaweeds may be useful in carbonization process [20]. In addition, seaweed has high ash content which contains larger amount of alkali and alkaline earth species than land-based biomass [21,22]. It is well known that the gasification activity of carbon in carbonaceous materials can be greatly enhanced by various alkali and alkaline earth metal compounds [23-28]. Several studies also indicated that alkali and alkaline earth species such as $\mathrm{K}$ and Ca play a key role in the formation of active sites for the surface carbon gasification reaction. It can reduce tar production by means of either stopping tar formation initially or by catalyzing tar decomposition and decreasing the formation of char [27].

Recently, co-gasification of coal and biomass has been widely studied. Brown et al. [29] investigated the catalytic activity of alkali-rich biomass on co-gasification of coal and switchgrass and found that switchgrass, especially switchgrass ash, which contains large 
quantities of potassium, displayed excellent catalytic activity in coal gasification. Howaniec et al. [30] investigated the synergy effect of steam co-gasification of coal and biomass and found that the observed synergy effect was mainly attributed to the catalytic effect of $\mathrm{K}_{2} \mathrm{O}$ present in the ash blend. However, few studies are related to the co-gasification of land-based biomass and seaweeds. Particularly, the effect of alkali and alkaline earth species in seaweed ash on the gasification of land-based biomass has been not explored. Large quantities of alkali and alkaline earth species contained in the brown seaweed may provide a potential source of inexpensive catalysts in the co-processing of land-based biomass and brown seaweed. In the present study, the steam gasification of brown seaweed (Sargassumhorneri), land-based biomass (Japanese cedar and Apple branch) and mixed biomasses between brown seaweed and Japanese cedar were carried out, and the effects of varying the gasification operating parameters on gas production yields were investigated and discussed. The objective was to clarify the promoting effects of seaweeds on the gasification of land-based biomass.

\section{Experimental}

\subsection{Materials}

Brown seaweed (Sargassum horneri (Turner) C.Agardh), Apple branch and Japanese cedar obtained from Aomori Prefecture, Japan were used as biomass samples. Brown seaweed 
was washed in fresh water to remove out the impurity adhered on the surface at first and dried in oven at $105{ }^{\circ} \mathrm{C}$ before storage and further use; Apple branch and Japanese cedar were also dried at the same conditions. Proximate analyses were performed according to ASTM D7582 standards, while ultimate analyses were conducted using Vario EL cube elemental analyzer. The compositions of biomass ash after calcination at $800{ }^{\circ} \mathrm{C}$ for $3 \mathrm{~h}$ in air were analyzed by XRF analysis (Energy Dispersive X-Ray Spectrometer, EDX-800HS, Shimadzu).

\subsection{Steam gasification of biomass}

Steam gasification of biomass was carried out by using a fixed-bed reactor with an internal diameter and a length of 18 and $350 \mathrm{~mm}$, respectively. A schematic diagram of the experimental setup is shown in Fig. 1. For each run, $0.6 \mathrm{~g}$ of oven-dried biomass was loaded into the vertical fixed-bed reactor. The reactor was placed inside an electrical furnace, which provided the heat for reactions. The heater was started at room temperature with a heating rate of $20{ }^{\circ} \mathrm{C} / \mathrm{min}$ and held at the desired temperature. The reactions were performed at atmospheric pressure with a temperature in the range of $650-750{ }^{\circ} \mathrm{C}$. Water was introduced by peristaltic pump into a vaporization furnace $\left(250{ }^{\circ} \mathrm{C}\right)$ and then was carried to the reactor by argon (carrier gas) with flow rate $50 \mathrm{~cm}^{3} / \mathrm{min}$. In our previous study [31], it is found that the gas yield after $2 \mathrm{~h}$ reaction was very low. Therefore, in this study, the reaction time was fixed at $2 \mathrm{~h}$ for each test. The gases 
produced were passed through a cold trap and collected in a gas bag. The gas compositions were analyzed using a gas chromatograph (Agilent 7890A GC system), in which one TCD with 3 packed columns (1 molecular sieve 5A column +1 HayeSep Q column +1 molecular sieve 5A column) was for the separation of $\mathrm{CO}, \mathrm{CH}_{4}$ and $\mathrm{CO}_{2}$ using $\mathrm{He}$ as carrier gas while the other TCD with a molecular sieve 5A for $\mathrm{H}_{2}$ measurement using $\mathrm{Ar}$ as the carrier gas. The carbon content in the remained char was estimated by using the elemental analyzer.

For the cogasification process, gas production yield was compared with the predicted yield of gas production $\left(Y_{\text {pred }}\right)$, which was the total yield when the two kinds of biomass were separately gasified. Predicted production yield was calculated as follow:

$Y_{\text {pred }}=X_{\text {bio1 } 1} \times Y_{\text {bio1 }}+\left(1-X_{\text {bio1 }}\right) \times Y_{\text {bio } 2}$

where $X_{\text {bio1 }}$ is the mass fraction of biomass 1 in the mix sample while $Y_{\text {bio1 }}$ and $Y_{\text {bio } 2}$ are gas or char production yields from biomass 1 and biomass 2 when they were separately gasified, respectively.

\section{Results and Discussion}

\subsection{Characteristics of biomass}

Proximate and ultimate analysis results of biomasses are shown in Table 1. The lowest carbon content was found in the brown seaweed. The ash contents of brown seaweed, apple 
branch, and Japanese cedar after calcination at $800{ }^{\circ} \mathrm{C}$ for $3 \mathrm{~h}$ in air were approximately 13.52 .0 and 0.6 wt\% , respectively, and their main composition are shown in Table 2 based on XRF analysis. It is found that brown seaweed had a higher ash content which contains a larger amount of alkali and alkaline earth species such as $\mathrm{K}$ and Ca than land-based biomass. Such alkali and alkaline earth species in biomass should have great influences on conversion processes because of their catalytic activities on pyrolysis and gasification [23-32].

\subsection{Steam gasification of various biomasses separately}

\subsubsection{Effect of biomass type}

The yield and composition of produced gases and other products during gasification of carbonaceous materials depend on the gasification conditions and the composition of feedstock. In the present work, in order to investigate the different steam gasification behaviors of land-based biomass and macroalgae, apple branch, Japanese cedar and brown seaweed were chosen as the biomass feed stock. The experiments were carried out in the fixed bed reactor at reaction temperature $700{ }^{\circ} \mathrm{C}$ with a water flow rate of $0.09 \mathrm{~g} / \mathrm{min}$ at room temperature. Fig. 2 shows the gas production yield obtained from each biomass sample during $2 \mathrm{~h}$. It can be seen that the steam gasification of brown seaweed gave the largest amount of gas product, especially $\mathrm{H}_{2}$ and $\mathrm{CO}_{2}$, than apple branch and Japanese cedar, and no char formation. Small quantities of 
$\mathrm{CH}_{4}$ were observed, indicating the occurrence of reforming reactions. Compared to land-based biomass which consists of cellulose, hemicelluloses and lignin, the main component in brown seaweed is the carbohydrates (sugars); protein and simple lipids are other constituents. Schumacher et al. [18] reported that carbohydrates can be more easily gasified than lignocellulosic biomass at $200-400{ }^{\circ} \mathrm{C}$ in supercritical water gasification condition. In present study, although the reaction was performed at ambient pressure, the reaction temperature was higher, and in this case, it is also found that the gas production yield from seaweed was much higher than those from land-based biomass. It is possible because that the carbohydrates (sugars) were easier to be gasified in such conditions than cellulose, hemicelluloses and lignin. The other important reason should be that large amount of alkali and alkaline earth species contained in brown seaweed could promote tar decomposition as well as char reforming during pyrolysis and steam gasification, increasing the carbon conversion to gas product. Alkali and alkaline earth catalysts have been reported to have good catalytic effects on steam gasification and several studies also indicated that alkali and alkaline earth species such as K and Ca play a key role in the formation of active sites for the surface carbon gasification reaction [23-32]. It could reduce the tar production by means of either stopping tar formation initially or by catalyzing the tar decomposition and decreased the formation of char. 


\subsubsection{Effect of reaction temperature}

Reaction temperature is one of the most significant operating parameters, which has an effect on the gaseous composition and carbon conversion throughout the oxidation and gasification reactions [33]. In the present study, in order to investigate the effect of reaction temperature on steam gasification of brown seaweed, the temperature of reactor was varied from 600 to $750{ }^{\circ} \mathrm{C}$ in $50{ }^{\circ} \mathrm{C}$ increments but the steam flow rate remained constant at $0.09 \mathrm{~g} / \mathrm{min}$. The test results are presented in Fig. 3. It can be seen that the total gas production yield increased sharply with temperature, especially $\mathrm{H}_{2}$ and $\mathrm{CO}_{2}$, and the content of char showed an opposite trend. However, when the gasification temperature was raised to $700{ }^{\circ} \mathrm{C}$, no char yield was observed, and the gas yields increased only a little if the reaction temperature increased higher. Higher temperature could enhance the endothermic gasification reactions such as steam gasification reactions: $\mathrm{C}+\mathrm{H}_{2} \mathrm{O} \rightarrow \mathrm{CO}+\mathrm{H}_{2}, \mathrm{C}+2 \mathrm{H}_{2} \mathrm{O} \rightarrow \mathrm{CO}_{2}+2 \mathrm{H}_{2}$ and the Boudouard reaction: $\mathrm{C}+\mathrm{CO}_{2} \rightarrow 2 \mathrm{CO}$, and result in more volatile release, promoting thermal cracking and providing the energy for endothermic reforming reaction of tar [34-36]. In addition, high temperature could enhance the catalytic activities of the large amount of alkali species, especially potassium (K) which is the effective catalysts in steam reforming the brown seaweed. Therefore higher $\mathrm{H}_{2}$ production can be obtained at higher reaction temperature. 


\subsubsection{Effect of water flow rate}

Increasing hydrogen production rate in biomass gasification process mainly involves (1) steam gasification, (2) reaction temperature, and (3) catalyst assistance [10]. In the present study, the steam was introduced in order to proceed to the steam reforming of tar and the water-gas shift (WGS) reactions $\left(\mathrm{H}_{2} \mathrm{O}+\mathrm{CO} \rightarrow \mathrm{CO}_{2}+\mathrm{H}_{2}\right)$. Thus, the amount of steam needs to be limited to obtain the highest hydrogen production yield. Therefore, the effect of water flow rate on the gas yields was investigated and the results are shown in Fig. 4. Comparing with non-steam system, it was found that with the introduction of steam, gas production yield increased sharply especially for $\mathrm{H}_{2}$ and $\mathrm{CO}_{2}$ yields. However, more increase in the water flow rate led to a slow increase in gas production yields first until the water flow rate was around $0.09 \mathrm{~g} / \mathrm{min}$, and then slightly decrease as the water flow rate increasing continually. This was probably due to the two reactions, i.e., steam reforming of tar and the water-gas shift (WGS) reactions. As excess water was introduced, it is possible that there was not enough biomass to react with all the steam added to reactor. Furthermore, excessive stream could result in temperature drop on the surface of biomass and in this case, reaction rates of the tar steam reforming and water-gas shift (WGS) could decrease to some extent. Similar results have been reported by other researchers $[34,35]$. Thus, in this work, the optimum value of water flow rate to achieve the maximum $\mathrm{H}_{2}$ yield occurred at a value of $0.09 \mathrm{~g} / \mathrm{min}$. 


\subsection{Steam co-gasification of land-based biomass and brown seaweed}

\subsubsection{Effect of addition weight ratio of brown seaweed}

In order to investigate the effect of addition of brown seaweed in the steam gasification of land-based biomass, the brown seaweed was co-gasified with Japanese cedar using different brown seaweed addition weight ratio. The brown seaweed weight ratio was defined as the ratio of gram of brown seaweed to the gram of total loaded biomass on dry basis. The experiment was performed at reaction temperature $700{ }^{\circ} \mathrm{C}$ and water flow rate of $0.09 \mathrm{~g} / \mathrm{min}$. Fig. 5(a) compares the total gas production yields from the cogasification of brown seaweed and Japanese cedar with the predicted production yields. The results show that the gas production yields from cogasification were higher than the predicted ones, suggesting that synergy effect happened in any cases. If all of brown seaweed was assumed to be gasified completely at the experimental condition and the gas and char yields produced from brown seaweed was removed from the total gas and char production yields, the effect of brown seaweed weight ratio on the char and gas production yields from steam gasification of Japanese cedar can be shown in Fig. 5(b). It clearly indicated that the amount of brown seaweed in the mixed biomass affected the gas production yield from steam gasification of Japanese cedar. One can see that steam gasification of the pure Japanese cedar gave a quite small amount of gas production yield. However, when brown 
seaweed was mixed with the Japanese cedar, it resulted in a higher gas production yields. With the increase in brown seaweed weight ratio, the $\mathrm{CO}$ and $\mathrm{CH}_{4}$ yields decreased a little, but the $\mathrm{H}_{2}$ and $\mathrm{CO}_{2}$ yields increased obviously while the char yields also decreased obviously. These results verified that the synergetic effect during the co-gasification of brown seaweed and Japanese cedar existed and more synergy occurred under a higher brown seaweed ratio. The observed synergetic effect could be mainly due to the catalytic effects of alkali and alkaline earth species in the brown seaweed. As shown above, brown seaweed had much higher ash content than Japanese cedar and especially contained more alkali elements such as potassium (K) than Japanese cedar. It has verified that potassium $(\mathrm{K})$ is one of the most effective catalysts for carbon gasification. In general, gasification of land-based biomass can produce larger amounts of tar. When brown seaweed and Japanese cedar were gasified together, the produced tar from Japanese cedar could be catalytically converted by the potassium $(\mathrm{K})$ contained in the brown seaweed via steam reforming reaction and produces more $\mathrm{H}_{2}$. On the other hand, as shown in Fig.2, since brown seaweed is much easier to be gasification than other biomass, more $\mathrm{H}$ and $\mathrm{OH}$ radicals could be released at first from the brown seaweed during the conversion and promote cracking of the aromatic rings in the Japanese cedar structure [37]. Furthermore, such radicals also can promote cracking of heavy tar to become light tar and gases [38]. Herein, it should be noted that gas yield was reduced slightly when brown seaweed weight ratio was increased higher than 0.83 
and the maximum gas production yield was observed at a brown seaweed ratio of 0.67 . It is possible that a larger amount gases such as hydrogen produced from the brown seaweed in the case of a higher weight ratio in the mixture could inhibit the steam gasification of the char of Japanese cedar to some extent during the co-gasification process. It is reported that hydrogen concentration in the gasifier had a large inhibiting effect on the biomass char gasification $[39,40]$

\subsubsection{Effect of reaction temperature}

Fig. 6(a) shows the effect of reaction temperature on the gas production yields from the steam co-gasification of Japanese cedar and brown seaweed with a brown seaweed ratio of 0.5 , and compared with the predicted ones. All the experiments were performed at different reaction temperature varied from 650 to $750{ }^{\circ} \mathrm{C}$ in $50{ }^{\circ} \mathrm{C}$ increments but the water flow rate was remained constant at $0.09 \mathrm{~g} / \mathrm{min}$. One can see that the synergy effect happened at any reaction temperatures. If all of brown seaweed was assumed to be gasified completely at the experimental condition and the gas and char yields produced from brown seaweed was removed from the total gas and char production yields, the effect of reaction temperature on the char and gas production yields from Japanese cedar in the steam co-gasification of Japanese cedar and brown seaweed can be obtained as shown in Fig. 6(b). As observed, the effect of reaction temperature is a very important factor in the gasification process. It is found that the total gas production yield from 
Japanese cedar increased sharply with the increase in temperature, especially for $\mathrm{H}_{2}$ and $\mathrm{CO}_{2}$, and the content of char showed an opposite trend. However, when the gasification temperature was raised to $750{ }^{\circ} \mathrm{C}$, no char yield was observed, indicating that all char in Japanese cedar was converted to gas. In addition, compared with the data shown in Fig.2, co-gasification experiments at $700{ }^{\circ} \mathrm{C}$ with brown seaweed ratio of 0.5 obtained approximately 1.62 times higher total gas production yields, suggesting that alkali and alkaline earth species in brown seaweed acted as a catalyst to enhance the gasification of Japanese cedar in co-gasification process.

\subsubsection{Effect of water flow rate}

Fig. 7(a) shows the effect of water flow rate on the gas production yields from the steam co-gasification of Japanese cedar and brown seaweed with a brown seaweed weight ratio of 0.5 at the reaction temperature $700{ }^{\circ} \mathrm{C}$, and compared with the predicted ones. The experiments were performed at different water flow rates varied from 0 to $0.2 \mathrm{~g} / \mathrm{min}$. One can see that the synergy effect happened at any water flow rates. If all of brown seaweed was assumed to be gasified completely at the experimental condition and the gas and char yields produced from brown seaweed was removed from the total gas and char production yields, the effect of water flow rate on the char and gas production yields from Japanese cedar in the steam co-gasification of 
Japanese cedar and brown seaweed can be obtained as shown in Fig. 7(b). It is found that with the introduction of steam, char yields decreased obviously while gas production yields increased sharply, especially for $\mathrm{H}_{2}$ and $\mathrm{CO}_{2}$ yields. Moreover, the rise of water flow rate led to a slow increase in gas production yields until values around $0.15 \mathrm{~g} / \mathrm{min}$, and then a slightly drop as water flow rate increasing continually. These results are similar to those indicated in section 3.2.3.

\section{Conclusions}

Three types of biomasses (brown seaweed, Japanese cedar, apple branch) and the mix of land-based biomass and macroalgae were gasified with steam in a fixed-bed reactor under atmospheric pressure in order to investigate catalytic activity of alkali and alkaline earth species in the biomass during separate biomass gasification and co-gasification. The following results were obtained:

1) Steam gasification of brown seaweed obtained a higher gas production yield, especially $\mathrm{H}_{2}$ and $\mathrm{CO}_{2}$, than other two biomasses. The ash content of brown seaweed was found to be much higher than land-based biomass and contains a large amount of alkali and alkaline earth species. These components in brown seaweed resulted in a self-catalytic activity for steam gasification. 
2) Co-gasification experiments showed the improvement on the gas production yield of land-based biomass when brown seaweed was added. The gas production yields, especially $\mathrm{H}_{2}$ and $\mathrm{CO}_{2}$, increased with the increase in brown seaweed weight ratio, suggesting that alkali and alkaline earth species in brown seaweed served as catalysts to enhance the gasification of land-based biomass in the co-gasification process.

3) Gasification conditions, especially steam amount and reaction temperature, had significant influence on the gasification performance of biomass. The steam was introduced in order to proceed to the steam reforming of tar as well as char. The yield of hydrogen increased with the rise of reaction temperature and steam amount for both systems. However, excessive steam reduces the hydrogen production yield.

\section{Acknowledgements}

This work is supported by Japan Science and Technology Agency (JST), Strategic International Collaborative Research Program (SICORP), Japan and Aomori City Government. M. Kaewpanha gratefully acknowledges the scholarship from the Ministry of Education, Culture, Sports, Science and Technology (MEXT) of Japan, and research fund for $\mathrm{PhD}$ course student from Hirosaki University. 


\section{References}

[1] G. Berndes, M. Hoogwijk, R.V.D. Broek, The contribution of biomass in the future global energy supply: a review of 17 studies, Biomass and Bioenergy 25 (2003) 1-28.

[2] M. Puig-Arnavat, J.C. Bruno, A. Coronas, Review and analysis of biomass gasification models, Renewable and Sustainable Energy Reviews 14 (2010) 2841-2851.

D. Świerczyński, S. Libs, C. Courson, A. Kiennemann, Steam reforming of tar from a biomass gasification process over Ni/olivine catalyst using toluene as a model compound, Applied Catalysis B: Environmental 74 (2007) 211-222.

[4] P. Lv, Z. Yuan, C. Wu, L. Ma, Y. Chen, N. Tsubaki, Bio-syngas production from biomass catalytic gasification, Energy Conversion and Management 48 (2007) 1132-1139.

[5] J. Han, H. Kim, The reduction and control technology of tar during biomass gasification/pyrolysis: An overview, Renewable and Sustainable Energy Reviews 12 (2008) 397-416.

[6] C. Courson, L. Udron, D. Świerczyński, C. Petit, A. Kiennemann, Hydrogen production from biomass gasification on nickel catalysts tests for dry reforming of methane, Catalysis Today 76 (2002) 75-86. 
[7] L. Devi, M. Craje, P. Thüne, K.J. Ptasinski, F.J.J.G. Janssen, Olivine as tar removal catalyst for biomass gasifiers: Catalyst characterization, Applied Catalysis A: General 294 (2005) 68-79.

[8] T. Furusawa, A. Tsutsumi, Comparison of $\mathrm{Co} / \mathrm{MgO}$ and $\mathrm{Ni} / \mathrm{MgO}$ catalysts for the steam reforming of naphthalene as a model compound of tar derived from biomass gasification, Applied Catalysis A: General 278 (2005) 207-212.

[9] L. Shen, Y. Gao, J. Xiao, Simulation of hydrogen production from biomass gasification in interconnected fluidized beds, Biomass and Bioenergy 32 (2008) 120-127.

[10] B.S. Huang, H.Y. Chen, K.H. Chuang, R.X. Yang, M.Y. Wey, Hydrogen production by biomass gasification in a fluidized bed reactor promoted by an $\mathrm{Fe} / \mathrm{CaO}$ catalyst, International Journal of Hydrogen Energy 37 (2012) 6511-6518.

[11] Y. Wang, K. Yoshikawa, T. Namioka, Y. Hashimoto, Performance optimization of two-staged gasification system for woody biomass, Fuel Processing Technology 88 (2007) 243-250.

[12] J. Zhou, Q. Chen, H. Zhao, X. Cao, Q. Mei, Z. Luo, K. Cen, Biomass-oxygen gasification in a high-temperature entrained-flow gasifier, Biotechnology Advances 27 (2009) 606-611. 
[13] P. Lv, Z. Yuan, L. Ma, C. Wu, Y. Chen, J. Zhu, Hydrogen-rich gas production from biomass air and oxygen/steam gasification in a downdraft gasifier, Renewable Energy 32 (2007) 2173-2185.

[14] K. Murakami, M. Sato, T. Kato, K. Sugawara, Influence of difference in chemical compositions of rice straw on hydrogen formation in nickel-catalyzed steam gasification, Fuel Processing Technology 95 (2012) 78-83.

[15] S. Cheah, K.R. Gaston, Y.O. Parent, M.W. Jarvis, T.B. Vinzant, K.M. Smith, N.E. Thornburg, M.R. Nimlos, K.A. Magrini-Bair, Nickel cerium olivine catalystfor catalytic gasification of biomass, Applied Catalysis B: Environmental 134-135 (2013) 34-45.

[16] S.G. Wi, H.J. Kim, S.A. Mahadevan, D.J. Yang, H.J. Bae, The potential value of the seaweed Ceylon moss (Gelidium amansii) as an alternative bioenergy resource, Bioresource Technology 100 (2009) 6658-6660.

[17] M.F. Demirbas, Biofuels from algae for sustainable development, Applied Energy 88 (2011) 3473-3480.

[18] M. Schumacher, J. Yanık, A. Sınağ, A. Kruse, Hydrothermal conversion of seaweeds in a batch autoclave, The Journal of Supercritical Fluids 58 (2011) 131-135. 
[19] W.A.J.P. Wijesinghe, Y.J. Jeon, Enzyme-assistant extraction (EAE) of bioactive components: A useful approach for recovery of industrially important metabolites from seaweeds: A review, Fitoterapia 83 (2012) 6-12.

[20] H. Haykiri-Acma, S. Yaman, S. Kucukbayrak, Production of biobriquettes from carbonized brown seaweed, Fuel Processing Technology 106 (2013) 33-40.

[21] L.E. Rioux, S.L. Turgeon, M. Beaulieu, Effect of season on the composition of bioactive polysaccharides from the brown seaweed Saccharina longicruris, Phytochemistry 70 (2009) 1069-1075.

[22] P. Rupérez, Mineral content of edible marine seaweeds, Food Chemistry 79 (2002) 23-26.

[23] L.X. Zhang, S. Kudo, N. Tsubouchi, J.I. Hayashi, Y. Ohtsuka, K. Norinaga, Catalytic effects of $\mathrm{Na}$ and $\mathrm{Ca}$ from inexpensive materials on in-situ steam gasification of char from rapid pyrolysis of low rank coal in a drop-tube reactor, Fuel Processing Technology 113 (2013) 1-7.

[24] K. Mitsuoka, S. Hayashi, H. Amano, K. Kayahara, E. Sasaoaka, M.A. Uddin, Gasification of woody biomass char with $\mathrm{CO}_{2}$ : The catalytic effects of $\mathrm{K}$ and Ca species on char gasification reactivity, Fuel Processing Technology 92 (2011) 26-31. 
[25] Y. Wu, J. Wang, S. Wu, S. Huang, J. Gao, Potassium-catalyzed steam gasification of petroleum coke for $\mathrm{H}_{2}$ production: Reactivity, selectivity and gas release, Fuel Processing Technology 92 (2011) 523-530.

[26] R. Muangrat, J.A. Onwudili, P.T. Williams, Influence of alkali catalysts on the production of hydrogen-rich gas from the hydrothermal gasification of food processing waste, Applied Catalysis B: Environmental 100 (2010) 440-449.

[27] P. Kuchonthara, T. Vitidsant, A. Tsutsumi, Catalytic effects of potassium on lignin steam gasification with $\gamma-\mathrm{Al}_{2} \mathrm{O}_{3}$ as a bed material, Korean Journal of Chemical Engineering 25 (2008) 656-662.

[28] L.D. Felice, C. Courson, P.U. Foscolo, A. Kiennemann, Iron and nickel doped alkaline-earth catalysts for biomass gasification with simultaneous tar reformation and $\mathrm{CO}_{2}$ capture, International Journal of Hydrogen Energy 36 (2011) 5296-5310.

[29] R.C. Brown, Q. Liu, G. Norton, Catalytic effects observed during the co-gasification of coal and switchgrass, Biomass and Bioenergy 18 (2000) 499-506.

[30] N. Howaniec, A. Smolinski, K. Stanczyk, M. Pichlak, Steam co-gasification of coal and biomass derived chars with synergy effect as an innovative way of hydrogen-rich gas production, International Journal of Hydrogen Energy 36 (2011) 14455-14463. 
Fushimi, A. Tsutsumi, Catalytic steam reforming of biomass tar over iron- or nickel-based catalyst supported on calcined scallop shell, Applied Catalysis B: Environmental, 115-116 (2012) 159-168.

[32] CZ Li, Importance of volatile-char interactions during the pyrolysis and gasification of low-rank fuels- A review, Fuel 112 (2013) 609-623.

[33] L.E. Taba, M.F. Irfan, W.A.M.W. Daud, M.H. Chakrabarti, The effect of temperature on various parameters in coal, biomass and CO-gasification: A review, Renewable and Sustainable Energy Reviews 16 (2012) 5584-5596.

[34] F. Yan, S.Y. Luo, Z.Q. Hu, B. Xiao, G. Cheng, Hydrogen-rich gas production by steam gasification of char from biomass fast pyrolysis in a fixed-bed reactor: Influence of temperature and steam on hydrogen yield and syngas composition, Bioresource Technology 101 (2010) 5633-5637.

[35] S. Luo, B. Xiao, X. Guo, Z. Hu, S. Liu, M. He, Hydrogen-rich gas from catalytic steam gasification of biomass in a fixed bed reactor: Influence of particle size on gasification performance, International Journal of Hydrogen Energy 34 (2009) 1260-1264. 
[36] X. Xiao, D.D. Le, L. Li, X. Meng, J. Cao, K. Morishita, T. Takarada, Catalytic steam gasification of biomass in fluidized bed at low temperature: Conversion from livestock manure compost to hydrogen-rich syngas, Biomass and Bioenergy 34 (2010) 1505-1512.

[37] M. J. Blesa, J. L. Miranda, R. Moliner, M. T. Izquierdo, J. M. Palacios, Low-temperature co-pyrolysis of a low-rank coal and biomass to prepare smokeless fuel briquettes. Journal of Analytical and Applied Pyrolysis, 70(2) (2003) 665-677.

[38] J. M. Jones, M. Kubacki, K. Kubica, A. B. Ross, A. Williams, Devolatilisation characteristics of coal and biomass blends. Journal of Analytical and Applied Pyrolysis, 74(1-2) (2005) 502-511.

[39] M.G. Lussier, Z. Zhang, D.J. Miller, Characterizing rate inhibition in steam/hydrogen gasification via analysis of adsorbed hydrogen, Carbon 36 (1998) 1361-1369.

[40] C. Fushimi, T. Wada, A. Tsutsumi, Inhibition of steam gasification of biomass char by hydrogen and tar, Biomass and Bioenergy 35 (2011) 179-185. 


\section{Figure captions}

Fig. 1 Schematic diagram of a fixed bed steam gasification system

Fig. 2 Product yields from different biomasses at a reaction temperature of $700{ }^{\circ} \mathrm{C}$ for $2 \mathrm{~h}$ (Water flow rate $=0.09 \mathrm{~g} / \mathrm{min}$

Fig. 3 Effect of reaction temperature on product yields from steam gasification of brown seaweed $($ Water flow rate $=0.09 \mathrm{~g} / \mathrm{min})$

Fig. 4 Effect of water flow rate on product yields (Reaction temperature $=700{ }^{\circ} \mathrm{C}$ )

Fig. 5 Effect of brown seaweed wight ratio on the cogasfication : (a) gas production yields from the co-gasification compared with the predicted ones; (b) product yields only from Japanese cedar in the co-gasification (Water flow rate $=0.09 \mathrm{~g} / \mathrm{min}$; reaction temperature $=700{ }^{\circ} \mathrm{C}$ ).

Fig. 6 Effect of reaction temperature on the cogasfication : (a) gas production yields from the co-gasification compared with the predicted ones ; (b) product yields only from Japanese cedar in the co-gasification (Water flow rate $=0.09 \mathrm{~g} / \mathrm{min}$; brown seaweed wight ratio $=0.5$ )

Fig. 7 Effect of steam flow rate on the cogasfication: (a) gas production yields from the co-gasification compared with the predicted ones ; (b) product yields only from Japanese cedar in the co-gasification (Temperature $=700{ }^{\circ} \mathrm{C}$; brown seaweed wight ratio $=0.5$ )

\section{Table captions}

Table 1. Proximate and ultimate analyses of biomass samples

Table 2. Main composition of ash in different biomasses 
Table 1. Proximate and ultimate analyses of biomass samples

\begin{tabular}{|c|c|c|c|c|c|c|c|c|}
\hline \multirow[t]{2}{*}{ Sample } & \multicolumn{3}{|c|}{ Proximate analysis (wt\%, dry basis) } & \multicolumn{5}{|c|}{ Ultimate analysis(wt\%, dry ash-free basis) } \\
\hline & Volatile matter & Fixed carbon & Ash & $\mathrm{C}$ & $\mathrm{H}$ & $\mathrm{N}$ & $\mathrm{S}$ & $\mathrm{O}^{\mathrm{a}}$ \\
\hline Brown seaweed & 52.8 & 33.7 & 13.5 & 39.2 & 5.0 & 1.9 & 1.5 & 52.4 \\
\hline Apple branch & 78.2 & 19.8 & 2.0 & 43.7 & 6.2 & 0.4 & 0.1 & 49.6 \\
\hline Japanese cedar & 86.9 & 12.5 & 0.6 & 48.8 & 6.6 & 1.4 & 0.2 & 43.0 \\
\hline
\end{tabular}


Table 2. Main compositions of ash in different biomasses

\begin{tabular}{lccc}
\hline \multirow{2}{*}{ Component } & \multicolumn{3}{c}{ Mass concentration \% } \\
\cline { 2 - 4 } & Seaweed & Apple & Cedar \\
\hline $\mathrm{CaO}$ & 40.57 & 65.85 & 50.68 \\
$\mathrm{SO}_{3}$ & 27.67 & 4.34 & 10.47 \\
$\mathrm{~K}_{2} \mathrm{O}$ & 12.86 & 8.33 & 4.01 \\
$\mathrm{SiO}_{2}$ & 10.53 & 1.75 & 6.83 \\
$\mathrm{SrO}$ & 3.96 & - & 0.04 \\
$\mathrm{P}_{2} \mathrm{O}_{5}$ & 3.87 & 8.18 & 6.45 \\
$\mathrm{Fe}_{2} \mathrm{O}_{3}$ & 0.34 & 0.22 & 0.80 \\
$\mathrm{MgO}$ & - & 9.81 & - \\
\hline
\end{tabular}




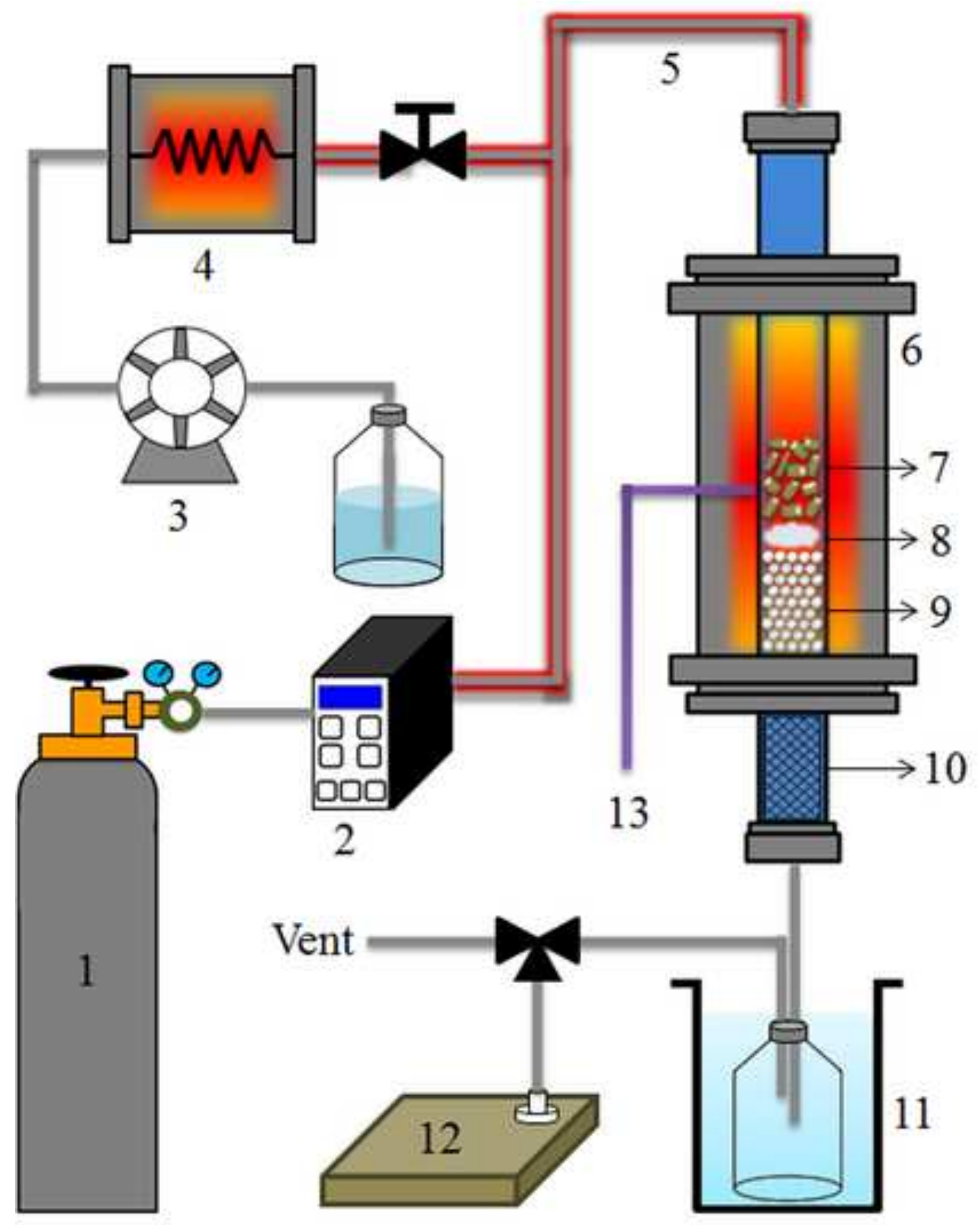

1. Carrier gas

2. Mass flow controller

3. Peristaltic pump

4. Steam generator

5. Ribbon heater

6. Electrical furnace

7. Sample

8. Quartz wool

9. Zirconia beads

10. Stainless mesh

11. Cooling bath

12. Gas bag

13. Thermocouple 


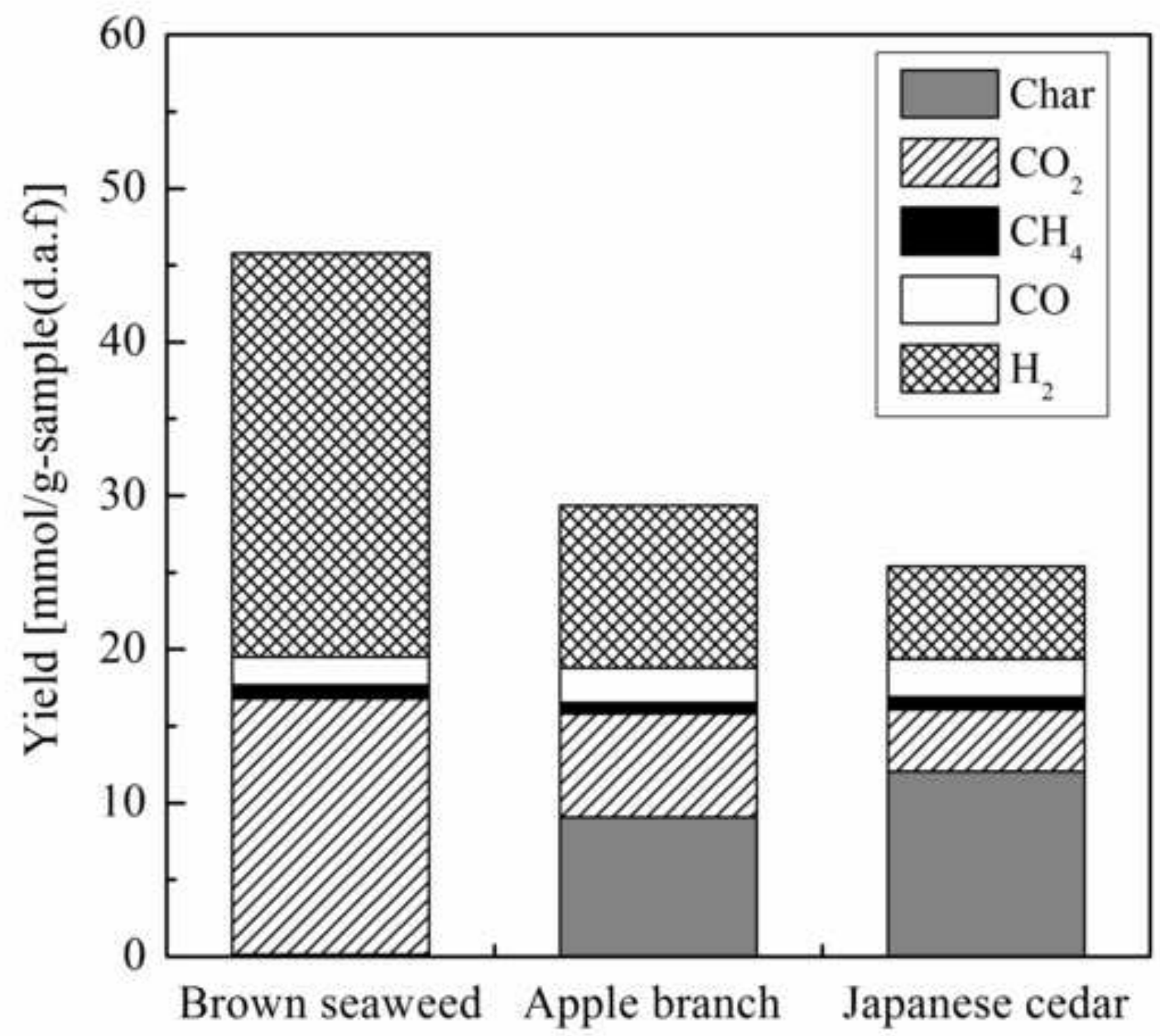




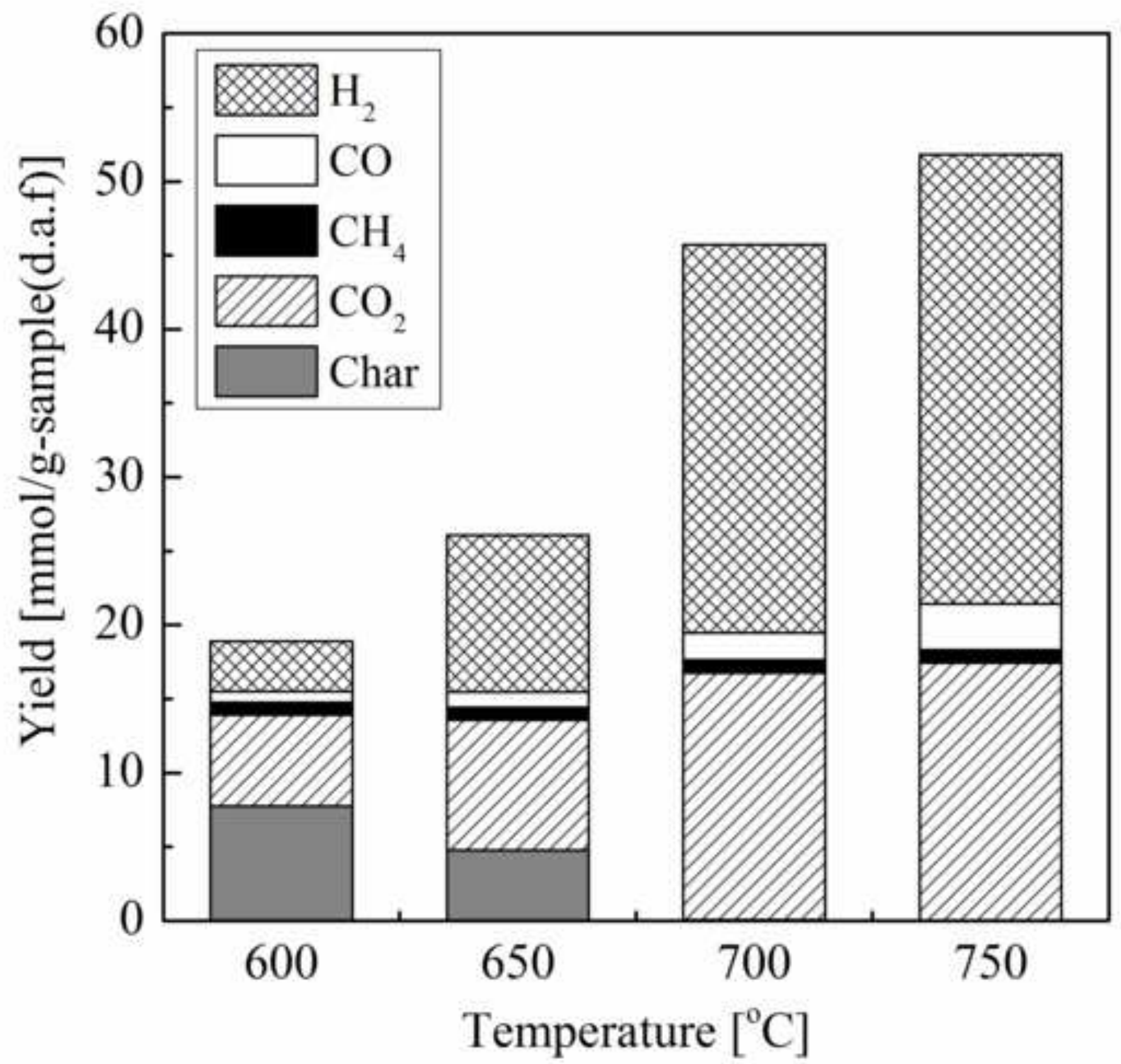




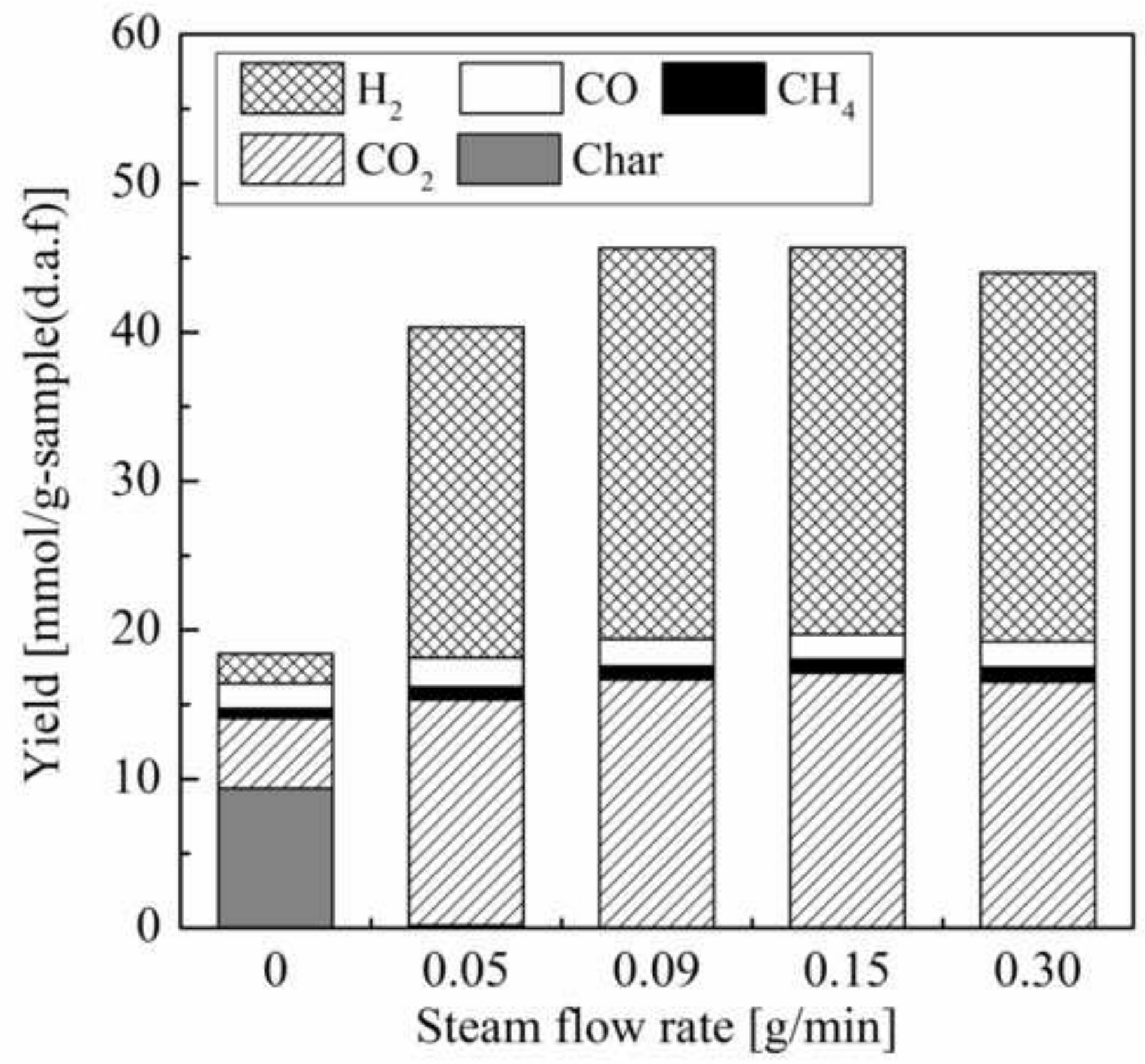



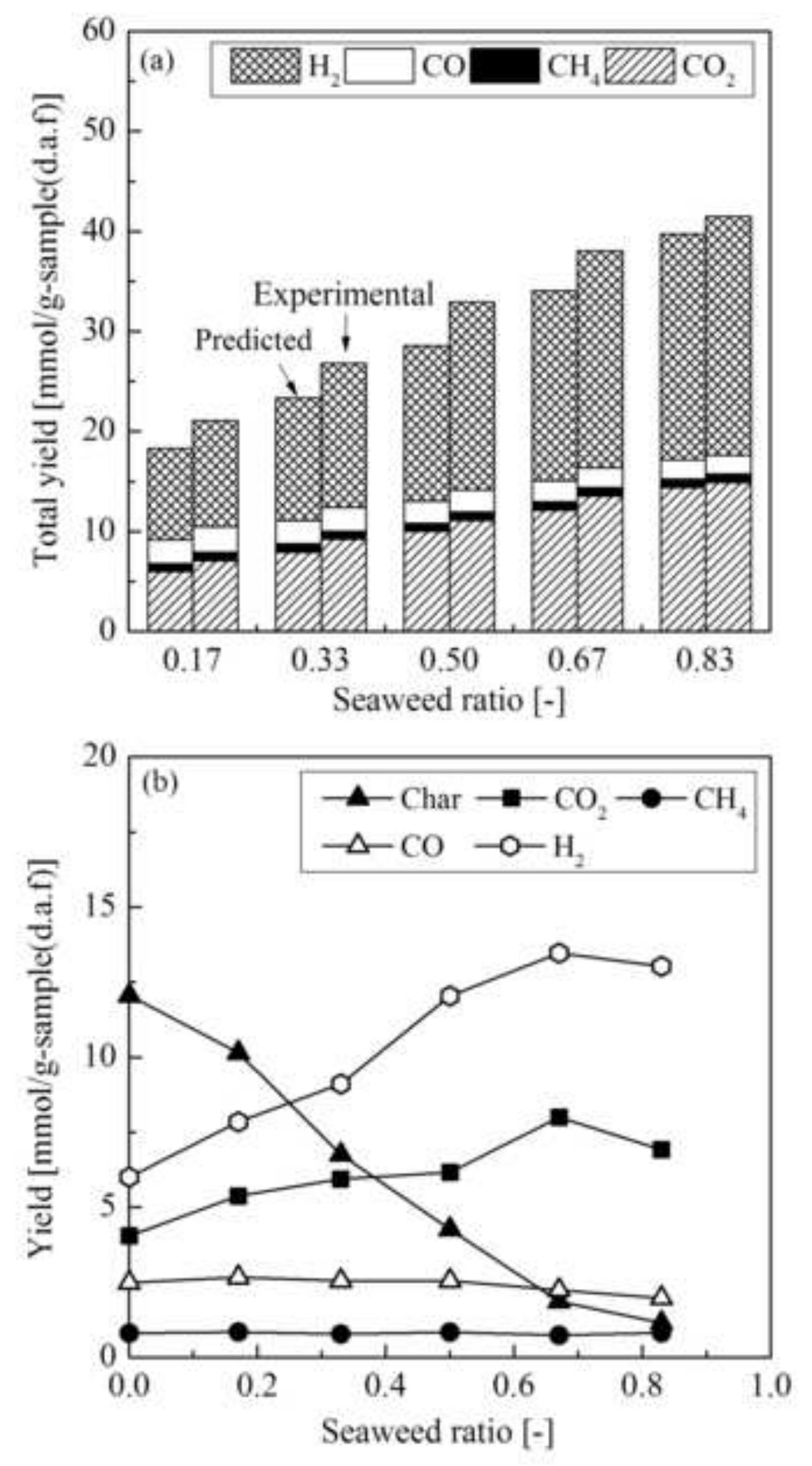

Figure-5-revised 

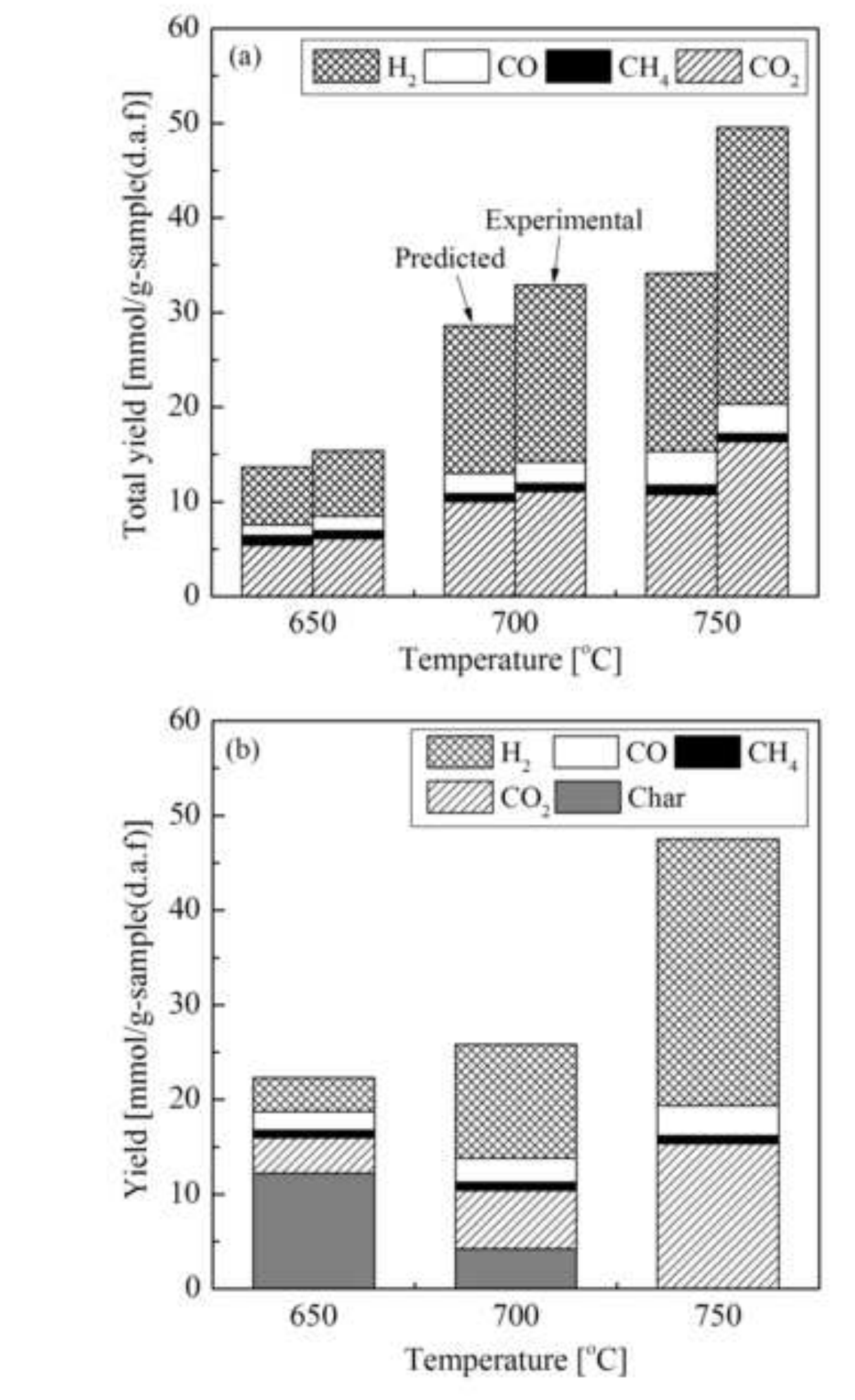

Figure-6-revised
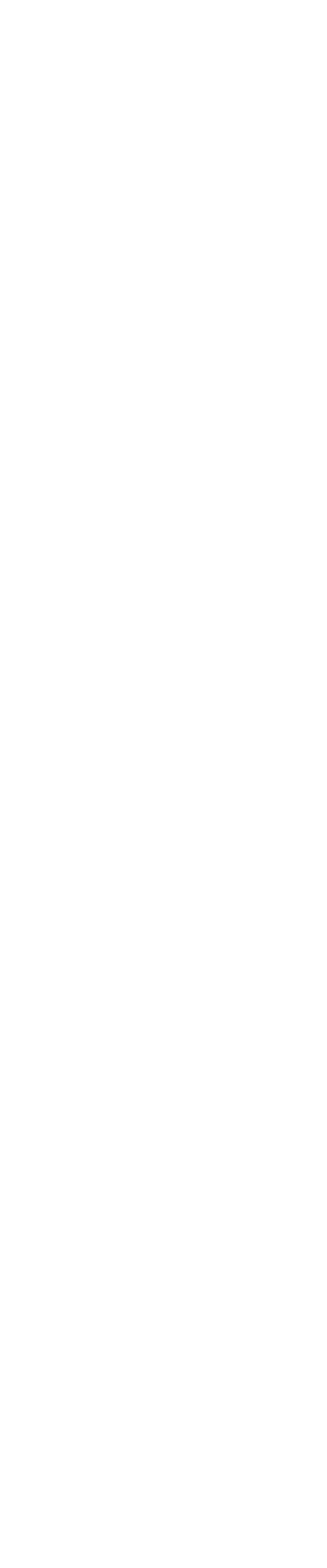

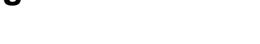

d

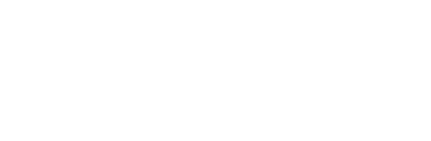



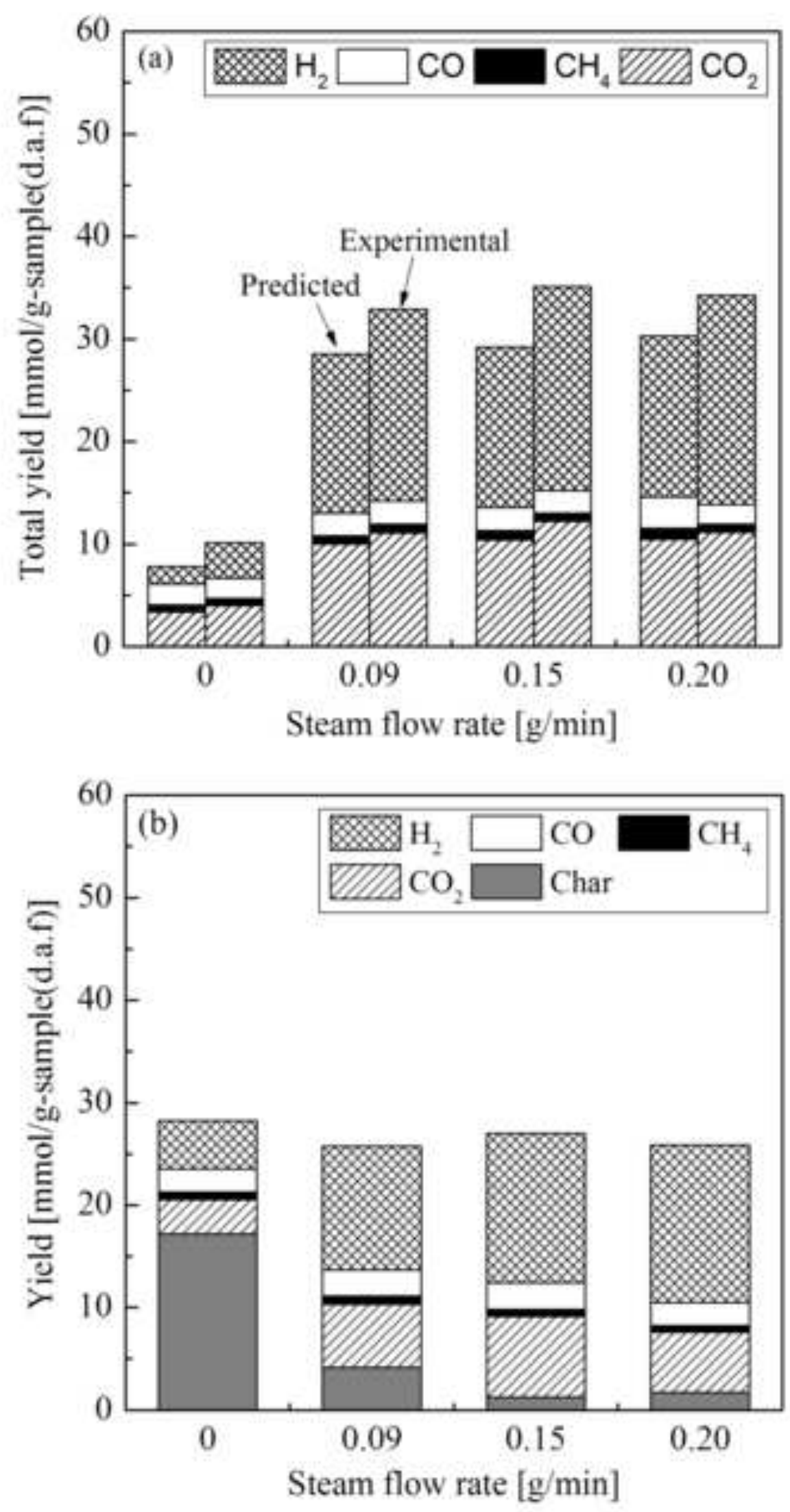

Figure-7-revised 


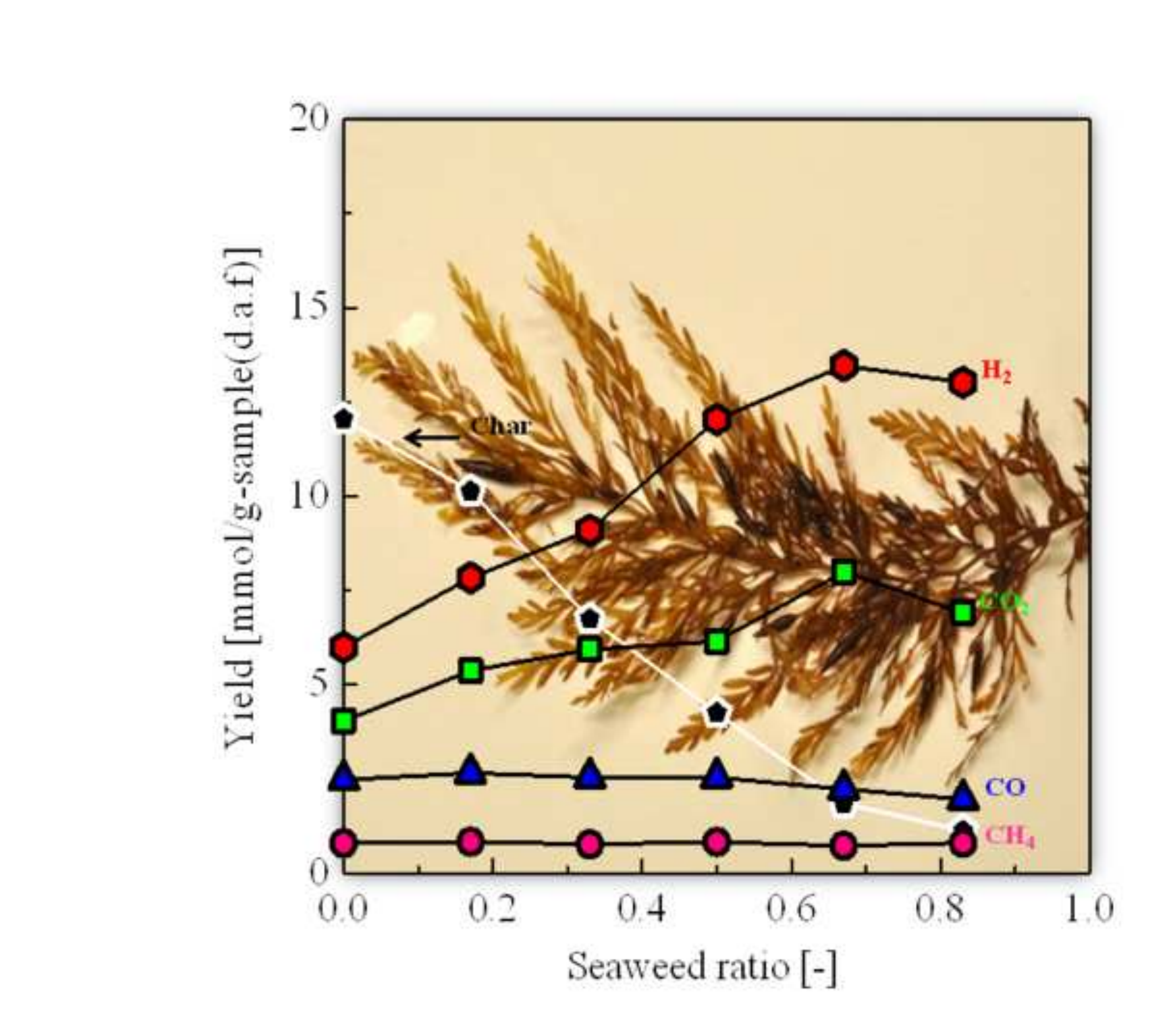

.

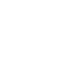

Graphical Abstract
\end{abstract}

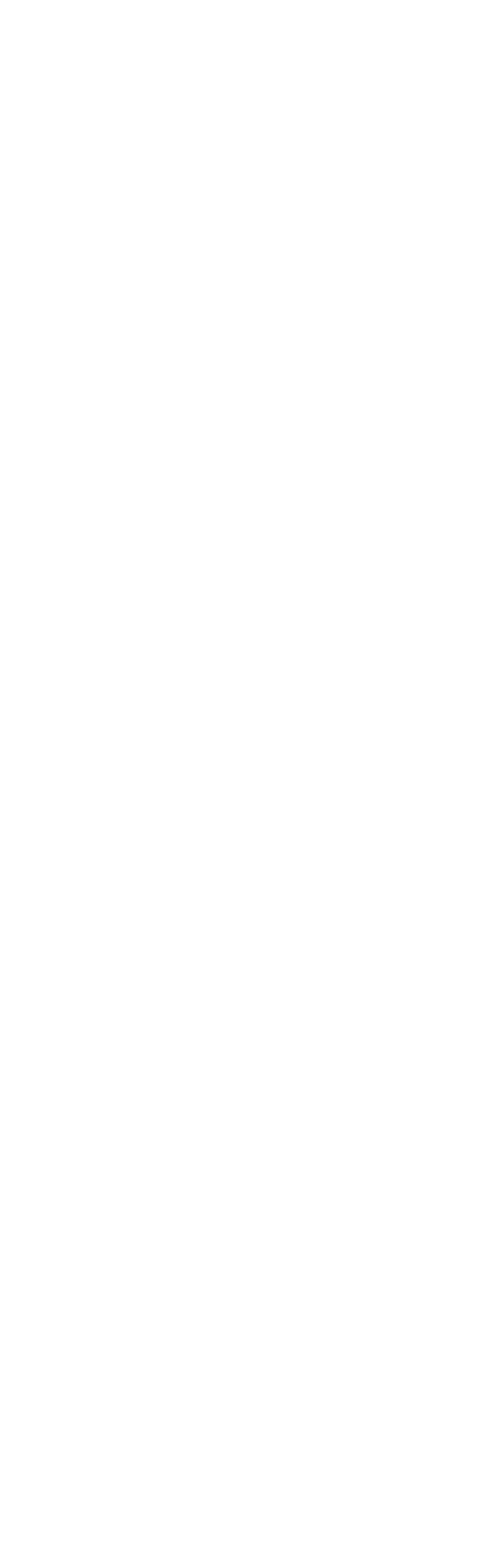

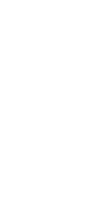

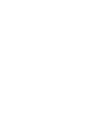

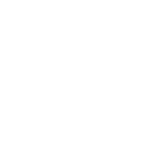

